\title{
An agenda for the Management of contemporary Sustainable houses
}

\author{
Dr. Ifeanyi Obi * \\ Department of Architecture, Girne American University, Turkey \\ E-mail: obiifeanyi@gau.edu.tr
}

\section{ART I CLEINFO: \\ Article history: \\ Received 16 April 2017 \\ Accepted 23 May 2017 \\ Available online 25 May 2017}

Keywords:

Sustainable planning;

Green building;

Design guidelines.

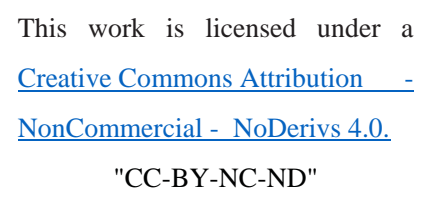

This work is licensed under a

Creative Commons Attribution

NonCommercial - NoDerivs 4.0. "CC-BY-NC-ND"

\begin{abstract}
A B S T R A C T
The evolution of sustainable design and Construction Management over the past ten years has produced a lot of literature on environmental sustainability and development. But despite this progress in the last ten years it is still a big challenge to designers, architects, landscape designers, etc. and all other professions that are related to the field of environmental science. . The goal of this paper is to simply create a framework for more accurate approach towards sustainable planning, design and development. The Objective of this paper includes to architecturally defining energy sustainable design in our sustainable Buildings; it is also to stress the concept of green building through design guidelines. This paper outlines, recommend and also create architectural design for sustainability and eliminate unsustainable elements in our building.

JOURNAL OF CONTEMPORARY URBAN AFFAIRS (2017) 1(2), 33-37.

https://doi.org/10.25034/ijcua.2017.3646
\end{abstract}

www.ijcua.com

Copyright (C) 2017 Journal Of Contemporary Urban Affairs. All rights reserved.

\section{Introduction}

\subsection{Sustainable Construction and Architecture}

Sustainable building could be defined as an environmentally designed building aimed to limit the effect on our natural environment. These could be achieved through the use of renewable resources or elements from the environment to build (construct) the building (Dawson, 2006). Our built environment involves many holistic approaches and this can be termed as a green approach. A green building could simply be defined as a building constructed on sustainable basic principles (Guy \& Farmer, 2006). This system of approach, in other words "Green Approach" is designed to measure and control the interaction between our man-made (Built Environment) and the environment. Therefore various elements of the building, for example, windows, floors, roofs etc can substantially increase or reduced the level of impact in our environment. In other words, the more sustainable they are, the less the negative impact on the building and the environment and vice versa (Ofori, 1998). Every element that are integrated together to make a building should

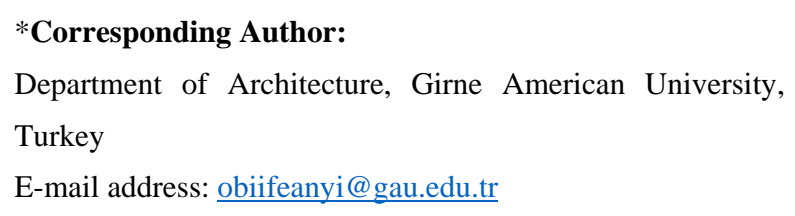


always be considered in other to achieve a sustainable building (Steemers, 2003).

An energy efficient building lays its emphasis on the health of the environment, dwellers and the future effect on other environmental factor like the climate. This study aims to use existing building elements in William's Ecovillage to create a framework for developing and evaluating the sustainability of buildings in Ecovillages in general, through research experiments on the building elements.

This research involves a case study of the building elements of the community house at William's Eco Village in Colrain, Massachusetts a start-up village; which will deliver the factors for the proposed ecological guidelines.

\subsubsection{Problems}

The evolution of sustainable design and Construction over the past ten years has produced a lot of literature on environmental sustainability and development. But despite this progress in the last ten years it is still a big challenge to designers, architects, landscape designers, etc. and all other professions that are related to the field of environmental science. From my study, I have come to realize that great percentage of factors that degrade our environment come from building activities and design of men. Designing of our man-made environment should as much as possible realign itself to the natural system of the environment. Attempts have been made to create a system of approach for sustainable development but none has clearly been defined over the years. Many authors have tried to develop a systematic approach to the environmental challenges we are facing today but not great many achievements have been made. There has been great extent of neglect on the building element, their quality and how they react to the environment.

\subsubsection{Design}

Differences in design also bring about difference in sustainable approach, most times sustainable developments in buildings are defined in general, without due to consideration to the different building types (Bonnette and Kirsten, 2004). For example sustainable approach for a residential building type might not be sustainable for commercial building type. Therefore, sustainable development should be defined individually as it affects each building design type (Hill, \& Bowen, 1997).

\subsubsection{Building}

Every building is made up of elements or building parts. These elements are integrated to form a building. Each element of any building is whole and has its own distinct capability and reaction to the same environmental factor. Throughout my literature review, I rarely came across literatures that dealt on the issue of building sustainability around its different element as this paper will do. Insulation, thermal massing, orientation are elements considered during building design so to neglect their relationship individually to sustainable design guidelines is tantamount to failure in creating design frame work for building sustainable development(Van Buerenn \& Priemus, 2002; Arenibafo, 2017; Alizadehsalehi et al., 2015). The relationship between design building element and sustainable frame work will be developed in the course of this paper.

\subsubsection{Case Study: The Community Building}

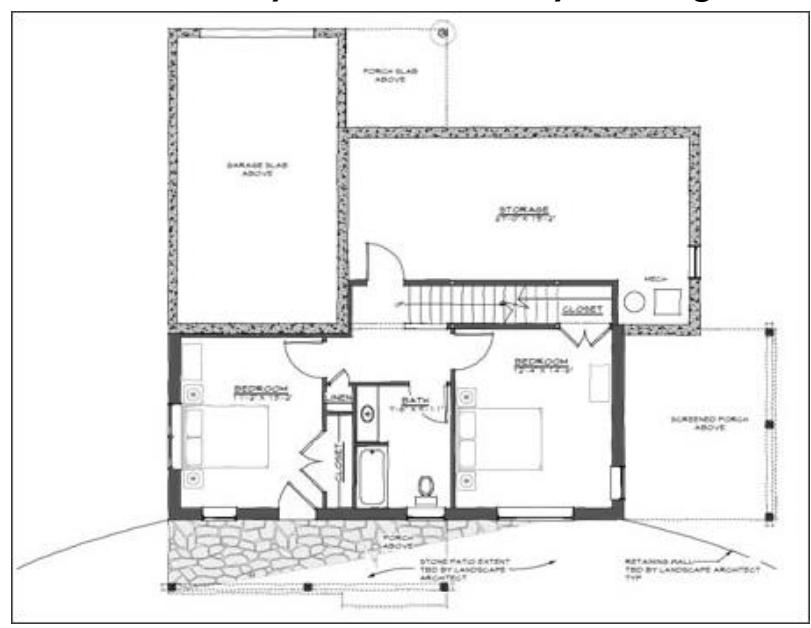

Figure 1. The Community Building, Ground Floor. 
Nestled into the hillside will be 17 south-facing houses in two clusters. The lower cluster of 12 three-quarter-acre lots will comprise Phase I along Crosier Lane; Phase II the upper five-lot cluster along Stowe Farm Lane. Between the two clusters is the existing house, a large redwood home built in 1972 with five guest rooms, a large party or meeting space, kitchen, library, and workshop. This building will serve, at least for the time being, as the community house.

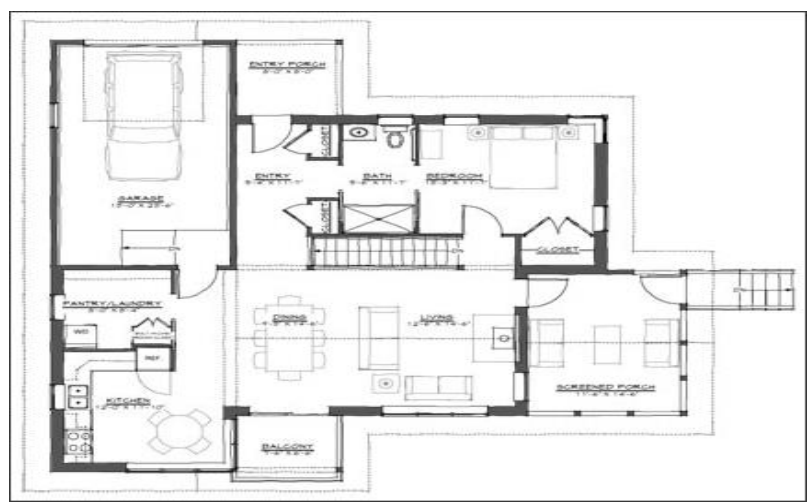

Figure 2. The Community Building, Upper Floor.

First (upper) floor: In the floor plan above, note that the north (top) wall has fewer windows than the south (bottom) wall, which overlooks Stone Mountain and the valley. Note also the differences in wall thickness: the thicker walls are a foot of blown-in, dense-packed cellulose, with an R-value of 45. Ceilings throughout are R-55.

Note the ramp from the garage into the panty and kitchen, the first floor of each house is designed using ADA (Americans with Disabilities Act) standards and approved by a consultant from Independent Living Resources. The entrance is ramped; doorways are wide enough for wheelchairs, and there are no thresholds. The first-floor bathroom is handicapped accessible. Each house has one garage space, a mudroom, a screened porch, and storage space.

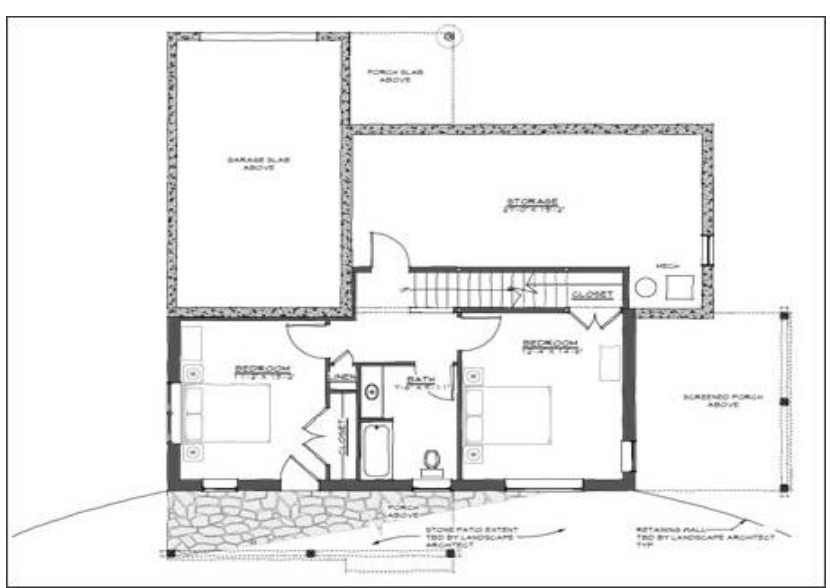

Figure 3. Comunity House, Lower Floor.

Second (lower floor): The lower floor has two guest bedrooms, one of which might be used for an office, and a bath. At the rear, there is a large storage and utilities room. For those who might need it, this floor could also be used as separate living space for a caregiver.

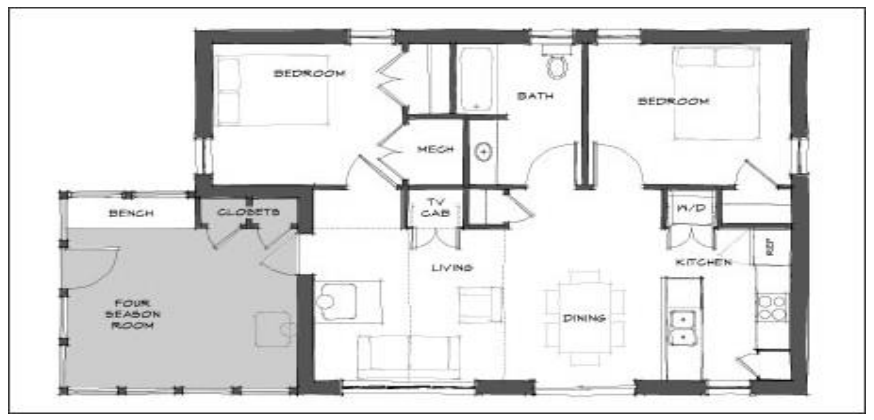

Figure 4. Mini House Floor Plan.

The Mini House echoes the design and planning of the Essential House on a smaller scale. A garage is optional.

Most of the challenges faced by different Ecovillages are their inability to follow the dynamic progress of sustainability in our buildings and environment in general. Over the last decade, various findings have brought into existence new principles and recommendations for eco-community development, suddenly already established eco-communities (Ecovillages) find themselves inadequate to 
meet up with the recommendations and standards set out for Ecovillages due to:

- Financial restraints,

- Environmental imbalances Example the topography is such that cannot be altered.

These factors I also found in the building at William's ecovillage built in 1972. The community house which will be the case study for this paper due to some environmental imbalances could not be improved upon to meet the new trend or standard in sustainable planning and design. The logic behind these general problems of various Ecovillages in the United States is that these ecocommunity buildings were designed on outdated sustainable principle. Seasonally new materials and principles of sustainable environment are developed. Experiments are done in various ecological labs to pursue better applications towards sustainability in our building and environment. Most of the problems encountered in William's ecovillage Community building are mainly on the various elements of the building. These elements were designed on previously acceptable sustainable design principles.

These problems are:

1. Orientation: I found out that the existing living building in William's ecovillage was not properly oriented. That is to mean a better part of the living area was located at the northern façade of the building, rather than the south façade of the building for better solar reach into the living areas.

2. Roofing: I found out from the complaint of sudden loss of heat energy in the building especially at night by the building occupant that the roofing materials not only that they are old but lack sufficient insulation against heat loss.

3. Wall Insulation: During my various researches at William's ecovillage building under construction, I easily noticed that the foundational walls were being constructed without an external insulation. These could easily lead to wetness of the basement wall.

4. Façade: During my research case study, I found out that the angle of the building to the sun path is improperly designed in that the building could have solar access into its interior spaces only when the sun is rising and at twelve o'clock noon during summer period

5. Window Design and Shapes: In my case study I found out that the windows on the building at William's ecovillage were designed using sliding window which are inefficient window design for passive cooling.

6. Thermal Mass: In a typical William's ecovillage building, I found out that the interior of the house are of wood which is not the best material for the kind of weather the ecovillage is situated in. Extremely cold winter and moderately hot summer weather.

\subsection{Solutions and Conclusions}

Sustainable buildings are not perfect buildings, because none exists. Sustainable building could be defined in line with the consumer culture of the occupants and also the climatic requirement of the region (Gilman, 1991). All through my study and research, I came to understand that various elements in a building could be used to measure out the sustainable level of any building under study. The achievement of sustainable development on our environment should be born in mind on the initial stage of conceptualization of design techniques. Various elements common in all buildings could be used as a yardstick to measure the sustainability of any building under study all over the world. These elements like:
A. Roof
B. Facade Design
C. Thermal mass
D. Windows shapes and sizes
E. Building orientation and design.
These factors mentioned above could be used as criteria of measuring sustainability in building. 
These elements are common to every building, so could be universally used as a yardstick in sustainable development and design. In this paper, experiments, Hypothesis, methodology and results on these elements of building, at William's were used as litmus for testing the sustainability of the common community house on William's eco-village Colrain, Massachusetts.

\section{Acknowledgments}

This research did not receive any specific grant from funding agencies in the public, commercial, or non-for-profit sectors.

\section{References}

Arenibafo, F. (2016). The Transformation of Aesthetics in Architecture from Traditional to Modern Architecture: A case study of the Yoruba (southwestern) region of Nigeria. Contemporary Urban Affairs (JCUA), $\quad 1(1), \quad 35-44 . \quad$ Doi: 10.25034/1761.1(1)35-44.

Alizadehsalehi, S., Koseoglu, O., \& Celikag, M. (2015). Integration of building information modeling (BIM) and laser scanning in construction industry. AEI 2015 (pp. 163-174). Milwaukee, Wisconsin.

Bonnette, R, and Kirsten, S. (2004.), "One Way to an Ecocentric Future: Ecovillages and the Ecovillage Movement in Anthropology." Senior Paper Thesis, The Department of Anthropology, The Colorado College, Colorado Springs, Colorado.

Dawson, R. (2006), Ecovillages: New Frontiers for Sustainability. Devon, UK: Green Books Ltd.

Gilman, R. (1991), The Eco-Village challenge, Context Institute publishers. (p.10)

Steemers, K. (2003), Establishing Research Directions In Sustainable Building Design. The Martin centre for architectural and urban studies, University of Cambridge.

Hill, R. C., \& Bowen, P. A. (1997). Sustainable construction: principles and a framework for attainment. Construction Management \& Economics, 15(3), 223-239.
Guy, S., \& Farmer, G. (2001). Reinterpreting sustainable architecture: the place of technology. Journal of Architectural Education, $54(3)$, 140-148.

Ofori, G. (1998). Sustainable construction: principles and a framework for attainmentcomment. Construction Management \& Economics, 16(2), 141-145.

Van Bueren, E. M., \& Priemus, H. (2002). Institutional barriers to sustainable construction. Environment and Planning $B$ : Planning and Design, 29(Bonnette and Kirsten, 2004), 75-86. 